\title{
Neutrophil Elastase Is Produced by Pulmonary Artery Smooth Muscle Cells and Is Linked to Neointimal Lesions
}

Yu-Mee Kim, Leila Haghighat, Edda Spiekerkoetter, Hirofumi Sawada, Cristina M. Alvira, Lingli Wang, Swati Acharya, Gabriela Rodriguez-Colon, Andrew Orton, Mingming Zhao, and Marlene Rabinovitch

From the Department of Pediatrics and the Wall Center for Pulmonary Vascular Disease, Stanford University School of Medicine, Stanford, California

Previously, we reported that murine gammaherpesvirus-68 (M1-MHV-68) induces pulmonary artery (PA) neointimal lesions in S100A4-overexpressing, but not in wild-type (C57), mice. Lesions were associated with heightened lung elastase activity and PA elastin degradation. We now investigate a direct relationship between elastase and PA neointimal lesions, the nature and source of the enzyme, and its presence in clinical disease. We found an association exists between the percentage of PAs with neointimal lesions and elastin fragmentation in S100A4 mice 6 months after viral infection. Confocal microscopy documented the heightened susceptibility of S100A4 versus C57 PA elastin to degradation by elastase. A transient increase in lung elastase activity occurs in S100A4 mice, 7 days after M1-MHV-68, unrelated to inflammation or viral load and before neointimal lesions. Administration of recombinant elafin, an elastasespecific inhibitor, ameliorates early increases in serine elastase and attenuates later development of neointimal lesions. Neutrophils are the source of elevated elastase (NE) in the S100A4 lung, and NE mRNA and protein levels are greater in PA smooth muscle cells (SMC) from S100A4 mice than from $\mathrm{C}_{57}$ mice. Furthermore, elevated NE is observed in cultured PA SMC from idiopathic PA hypertension versus that in control lungs and localizes to neointimal lesions. Thus, PA SMC produce NE, and heightened production and activity of $\mathrm{NE}$ is linked to experimental and clinical pulmonary vascular disease. (Am J Pathol 2011, 179:1560-1572; DOI: 10.1016/j.ajpath.2011.05.051)
Pulmonary arterial (PA) neointimal lesions are observed in patients with PA hypertension that is idiopathic (IPAH) or associated with other medical conditions. These vascular abnormalities cause narrowing and even obliteration of the vessel lumen and contribute to the progressive increase in pulmonary vascular resistance that can lead to right ventricular failure (reviewed in Ref. 1). Only a few murine or rodent models recapitulate this pathological feature, eg, mice exposed to ovalbumin or aspergillus ${ }^{2}$ or to schistosomiasis, ${ }^{3}$ rats treated with the vascular endothelial receptor blocker Sugen 5416, exposed to chronic hypoxia and recovered in room air, ${ }^{4}$ mice that overexpress IL-6 and are subjected to chronic hypoxia, ${ }^{5}$ or mice that overexpress S100A4. ${ }^{6}$ The latter mice, when over 1 year of age, can on rare occasions "spontaneously" develop severe neointimal lesions. ${ }^{6}$ However, these lesions are observed consistently following infection with murine gammaherpesvirus-68 (MHV-68). ${ }^{7}$ S100A4 is also known as metastasin-1 (mts-1), and is a member of the calcium binding family of proteins that clusters on chromosome 1 and that has been related to cancer and inflammation. ${ }^{8}$

The S100A4-overexpressing mouse infected with MHV-68 is relevant to clinical PAH. Increased immunoreactivity for S100A4 is observed in vascular lesions in patients with advanced $\mathrm{PAH},{ }^{6}$ and human immunodefi-

Supported by grants from the National Institutes of Health (NHLBI)-R21HL098782, the National Scleroderma Foundation and the Scleroderma Research Foundation (M.R.), and by a postdoctoral fellowship (Y.-M.K.), summer studentship (L.H., A.O.), and career development award (C.M.A.) from the American Heart Association (AHA), as well as postdoctoral fellowships from the AHA-Pulmonary Hypertension Association (E.S.) and Oak Foundation (H.S.), by the Summer Student Research Program at Stanford (G.R.-C.), and by the Vera and Dwight Dunlevie Endowed Chair in Pediatric Cardiology (M.R.).

Accepted for publication May 17, 2011.

Supplemental material for this manuscript can be found at $h t t p: / / a j p$. amjpathol.org or at doi: 10.1016/j.ajpath.2011.05.051.

Current address of H.S., Department of Pediatrics, Mie University Graduate School of Medicine, Mie, Japan.

Address reprint requests to Marlene Rabinovitch, M.D., Stanford University School of Medicine, CCSR, Room 1215, Stanford, CA 94305-5162. E-mail: marlener@stanford.edu. 
ciency virus (HIV) and HHV-8/Kaposi's sarcoma virus, the human homologue of MHV-68, have been implicated in clinical PAH. Specifically, the viral protein for HHV-8 has been detected in neointimal and plexiform lesions in lung tissues from some, ${ }^{9}$ albeit not all, ${ }^{10}$ series of PAH patients.

Pulmonary vascular neointimal and plexiform lesions in S100A4 mice are associated with fragmentation of elastic laminae and with heightened activity of a serine elastase. ${ }^{7}$ Fragmentation of PA elastin has been observed in PAs of PAH patients, ${ }^{11}$ and heightened activity of a serine elastase has been identified in the PA in a variety of experimental forms of $\mathrm{PAH}^{12-15}$ and in cultured $\mathrm{PA}$ smooth muscle cells (SMC). ${ }^{16-19}$ Moreover, inhibition of this elastase can attenuate or prevent ${ }^{12-14}$ and even reverse ${ }^{15}$ experimental pulmonary vascular disease in rodents. In all rodent models where elastase inhibitors were used, the pulmonary vascular lesions were characterized by loss or increased muscularization of normally nonmuscular peripheral arteries at the alveolar wall and duct level, and medial hypertrophy of proximal muscular arteries. Neointimal lesion formation, however, was not present. Elastase inhibition should, however, attenuate these lesions since proliferation and migration of SMC in the neointima are likely the consequences of elastasemediated release of growth factors from the extracellular matrix $^{16,17}$ and activation of growth factor receptors. ${ }^{20}$

We therefore hypothesized, and subsequently demonstrated in this study, that in the S100A4 overexpressing versus C57 mouse, heightened susceptibility of elastin to fragmentation, coupled to elevated serine elastase activity following M1-MHV-68 infection, can contribute to the development of neointimal lesions. We identified the elastase involved as neutrophil elastase (NE) produced by PA SMC, suggesting that it is the endogenous vascular elastase previously related to $\mathrm{PAH}$ in other experimental models. ${ }^{12,16,18,19}$ Moreover, we showed that NE is produced in significantly greater amounts by cultured murine S100A4 versus C57 PA SMC, and by human PA SMC from IPAH versus control lungs, and we localized $\mathrm{NE}$ to neointimal and plexiform lesions in human lung specimens.

\section{Materials and Methods}

\section{S100A4 Overexpressing Mice}

Transgenic mice overexpressing S100A4/Mts1 (originally obtained as a kind gift from Drs. Noona Ambartsumian and Eugene Lukanidin, Danish Cancer Society, Copenhagen, Denmark) were generated as previously described on a CBA $\times$ C57/Black-6 background and backcrossed to a C57 background. Briefly, strains of transgenic mice were created with the 450-bp cDNA sequence of the murine s100A4/mts 1 gene under the control of the 3-hydroxy-3-methylglutaryl CoA (HMGCoA) reductase gene promoter. ${ }^{21}$ The main phenotype of the mice is a high incidence of hemangiomas with aging. ${ }^{22}$ Female mice were used in all studies because males do not develop neointimal lesions. An explanation is provided in the studies of Dr. M. McLean, University of Glasgow, indicating that there is estrogen-mediated upregulation of the receptor for advanced glycation end products (RAGE) (unpublished observations) that is the receptor for S100A4. ${ }^{23}$ The number of C57BL/6 (C57) background (Jackson Laboratory Stock number 000664; Bar Harbor, ME) or S100A4 overexpressing mice used per group in each experiment is indicated in the figure legends. In some groups, mini-osmotic pumps (Model 1004) and jugular catheters purchased from Alzet (Palo Alto, CA) were implanted for intravenous infusion of recombinant elafin or vehicle. Recombinant elafin was a kind gift from Drs. Kalke and Wiedow (Proteo, Hamburg, Germany). After the hemodynamic assessment and before collection of tissues, euthanasia was performed using an overdose of $120 \mathrm{mg} / \mathrm{kg}$ of pentobarbital. All animal experiments were performed under a protocol approved by the animal care committee of Stanford University School of Medicine and were in compliance with the guidelines of the American Physiological Society.

\section{Morphometric Evaluation of Central PA Elastin by Confocal Microscopy}

The internal elastic lamina of the central PA was investigated using confocal microscopy. It is the autofluorescence of elastin that permits visualization of the internal elastic lamina and the fenestrations that perforate it. 24,25 The size of the fenestrations in the internal elastic lamina were assessed before and after elastase treatment as a measure of susceptibility of the elastin to degradation. ${ }^{26}$ For these studies, uninfected S100A4 or C57 mice at 1 year of age were euthanized with $120 \mathrm{mg} / \mathrm{kg}$ of pentobarbital and the heart and lungs were isolated en bloc. The lungs were either flushed slowly with PBS and perfused with PBS (controls), or flushed with PBS and perfused with PBS containing $5 \mu \mathrm{g} / \mathrm{mL}$ porcine pancreatic elastase (Invitrogen, Carlsbad, CA) and then immersed in the same solution for 20 minutes at $37^{\circ} \mathrm{C}$. The pulmonary vasculature was then fixed by perfusion at the right ventricular systolic pressure (described below), using $4 \%$ paraformaldehyde at room temperature for 5 minutes, and immersion-fixed for an additional 1 hour. The central PAs were removed and mounted lumen side down in glycerol on glass slides and then visualized with a Leica SP2 confocal system fitted with an inverted microscope and argon and helium-neon laser sources (Leica Microsystems, Wetzlar, Germany). Autofluorescence of elastin was excited at $488 \mathrm{~nm}$, and emission was detected at $500-$ to $560-\mathrm{nm}$ wavelengths. Serial optical sections ( $z$ step $=0.81 \mu \mathrm{m}$ ) from the lumen to adventitia were captured with an $\times 63$ oil objective and superimposed as nine images with the best visualization of the internal elastic lamina. For each PA, quantification of the number and size of fenestrations in the elastic lamina was assessed in six separate fields at $\times 400$ magnification using the Bioquant image analysis system (Bioquant Image Analysis Corporation, Nashville, TE). 


\section{Hemodynamic and Structural Evaluation of PAH}

We evaluated the presence of PAH in mice 6 months after viral or saline infection by measurement of right ventricular (RV) systolic pressure and by right ventricular hypertrophy as described. ${ }^{27}$ Briefly, RV systolic pressure, RV $\mathrm{dp} / \mathrm{dt}$, and heart rate were measured in unventilated mice that were under isoflurane anesthesia (1.5\% to $2.5 \%, 2 \mathrm{~L}$ $\mathrm{O}_{2} / \mathrm{min}$ ) using a closed chest technique, by introducing a 1.4-F Millar catheter into the jugular vein and directing it to the right ventricle. The lungs were then flushed with warm isotonic saline through a vented left atrium to clear blood, and the heart and lungs were removed en bloc. The left lung was perfused for morphometric studies described below, and the right lung was snap frozen in liquid nitrogen and stored at $-80^{\circ} \mathrm{C}$. Right ventricular hypertrophy was later evaluated by weight of right ventricle/left ventricle plus septum $(R V / L V+S)$.

\section{Implantation of Osmotic Pumps and Intravenous Infusion of Recombinant Elafin}

Mini-osmotic pumps containing saline (vehicle) or elafin were implanted under isoflurane anesthesia $(1.5 \%$ to $2.5 \%$ isofluorane in $2 \mathrm{~L} \mathrm{O}_{2} / \mathrm{min}$.), subcutaneously in mice on the back, slightly posterior to the scapulae. The delivery port of the osmotic pump was connected to a catheter implanted in the external jugular vein for intravenous infusion of saline or elafin. Recombinant elafin was reconstituted with saline and administered as a $2 \mathrm{mg} / \mathrm{kg}$ bolus followed by a $2 \mathrm{mg} / \mathrm{kg}$ per day continuous intravenous infusion at an hourly rate of $0.11 \mu \mathrm{L}$ for 4 weeks. The dose of elafin used in this study prevented the increase in lung elastase activity observed 1 week after viral infection. It is similar to the dose used to attenuate postcardiac transplant coronary arteriopathy. ${ }^{28}$

\section{Histology and Immunohistochemistry}

We used $10 \%$ formalin or zinc fixative to perfuse the left lung at the in vivo pressure for histological and immunohistochemical morphometric studies. The lung was inflated with $10 \%$ formalin or zinc fixative at $20 \mathrm{~cm} \mathrm{H}_{2} \mathrm{O}$ pressure. Zinc fixation was necessary to label cells with antibodies that recognize neutrophils (Ly-6G) or macrophages (Mac-3). For immunohistochemical analyses of $10 \%$ formalin-fixed tissues, slides were deparaffinized in xylene (twice for 5 minutes) and hydrated in 100\% (twice), 95\%, 90\%, and 70\% ethanol (3 minutes each). Antigen retrieval was performed for $10 \%$ formalin-fixed tissues using the heat-mediated citrate buffer antigen retrieval method [10 mmol/L sodium citrate, $0.05 \%$ Tween $20(\mathrm{pH} \mathrm{6.0)].} \mathrm{Staining} \mathrm{was} \mathrm{performed} \mathrm{using} \mathrm{the} \mathrm{Vec-}$ tastain Elite ABC kit (Vector Laboratories, Burlingame, CA) according to the manufacturer's protocol. Primary antisera used in this study were mouse anti-PCNA (1:100) (Invitrogen), rat anti-mouse Ly-6G (1: 100) (eBiosciences, San Diego, CA), rat anti-mouse Mac-3 (1:100) (BD Pharmingen, San Diego, CA), and mouse anti-human neutrophil elastase (1: 100) (Dako, Glostrup, Denmark). Stable DAB (Invitrogen) was used as a substrate for horseradish peroxidase. Slides were rinsed, counterstained with hematoxylin (Sigma, St. Louis, MO) for 20 seconds, rehydrated in graded ethanol and xylene, and then covered with a coverslip.

Movat's pentachrome staining of formalin-fixed tissues was used to evaluate the formation of a neointima in intra-acinar arteries (50 to $300 \mu \mathrm{mol} / \mathrm{L}$ ). The thickness of the neointima was graded as follows: Grade I = one layer of neointimal cells, Grade $\|$ = two layers, and Grade $\| \mathrm{I}=$ three or more layers. Fragmentation or discontinuity of elastin that was not attributable to sectioning artifact was assessed using Hart's stain and quantified as the percentage of muscular pulmonary arteries with fragmented elastic laminae relative to the total number of muscular pulmonary arteries in the section.

\section{Extraction and Quantification of Viral DNA and RNA}

Central PAs were isolated from the heart and lung en bloc using a microdissection microscope (Leica MZ7.5). Peripheral PAs $(<200 \mu \mathrm{m}$ in diameter) were collected from formalin-fixed and paraffin-embedded lung tissue using a laser capture microscope (Leica AS LMD). Total DNA, including endogenous and viral DNA from central or peripheral PAs, was extracted using QIAamp DNA mini kit according to the manufacturer's instruction (Qiagen, Valencia, CA) and amplified using TaqMan PreAmp Master Mix kit (Applied Biosystems, Foster City, CA). Total RNA was extracted using the RNeasy mini kit (Qiagen) according to the manufacturer's instructions. The levels of viral DNA or RNA were detected by real-time PCR using the ABI Prism 7900HT sequence detector (Applied Biosystems). We used primers and probes specifically designed for MHV-68 glycoprotein B to detect a 70-bp region of the $\mathrm{MHV}-68$ glycoprotein $\mathrm{B}$ gene:

Forward, 5'-GGCCCAAATTCAATTTGCCT-3'; reverse, 5'-CCCTGGACAACTCCTCAAGC-3'; probe 5'-6-(FAM)ACAAGCTGACCACCAGCGTCAACAAC-TAMRA-3', where FAM is a reporter dye and TAMRA is a quencher dye. ${ }^{29}$ Ten nanograms of DNA extracted from each mouse lung were used per reaction.

\section{Elastase Activity Assay}

Measurement of elastase activity from murine lung tissue was performed following instructions provided in the EnzChek elastase assay kit (Invitrogen) as previously described. ${ }^{7}$ Briefly, murine lung tissue $(30 \mathrm{mg}$ ) was homogenized and centrifuged at $3300 \times g$ for 30 minutes at $4^{\circ} \mathrm{C}$ to collect the pellet as the source of elastase. The pellet was extracted and precipitated as described ${ }^{7}$ to enrich for elastase, and elastase activity was measured using the fluorogenic substrate bovine $D Q$ elastin in the absence or presence of a serine elastase inhibitor ( $N$-methoxysuccinyl-Ala-Ala-Pro-Val-chloromethyl ketone). Serine elastase activity was calculated in fluorescent units as the elastase activity that was inhibited. Elastase activity was monitored in primary mouse PA SMCs (passage number 4 to 7 ) by incubating bovine $D Q$ elastin (final 
concentration, $25 \mu \mathrm{g} / \mathrm{mL}$ ) in serum-free and phenol redfree cell culture medium for 24 hours. To measure serine elastase activity, samples were treated with elafin in a final concentration of $2 \mu \mathrm{g} / \mathrm{mL}$ before incubation with $\mathrm{DQ}$ elastin, and the difference in fluorescence when compared to the non-elafin-treated samples was recorded as (elafin-inhibitable) serine elastase activity.

\section{Purification of Elafin-Bound Elastase}

Subcloning, expression, and purification of $\mathrm{NH}_{2}$-terminus FLAG-tagged mature elafin (6 kDa) was performed by GenScript (Piscataway, NJ) following the sequence that we previously published. ${ }^{28}$ The FLAG-elafin was conjugated to a FLAG affinity column using a FLAG-tagged protein immunopreciptation kit (Sigma). Protein extracts were prepared as described above for the elastase activity assays, using lungs of S100A4 mice 7 days after inoculation with M1-MHV-68. After thorough washing of the column, the proteins that were specifically bound to FLAG-elafin were released into the elution buffer by $3 \times$ FLAG peptides. These elafin-bound proteins were identified by mass spectrometry (matrix-assisted laser desorption/ionization-time-of-flight mass spectrometer) (Proteomics Core Facility, Stanford University School of Medicine).

\section{Elastin Zymography}

Sodium dodecyl sulfate polyacrylamide gel electrophoresis (SDS-PAGE) substrate-embedded enzymography (zymography) was performed using a 10\% acrylamide gel containing $1 \mathrm{mg} / \mathrm{mL}$ soluble elastin (Elastin Products, Owensville, MO) incubated with $100 \mu \mathrm{g}$ of the lung protein extract prepared as described above for mass spectrometry analysis. Human leukocyte elastase and porcine pancreatic elastase (Elastin Products) were used as positive controls. Electrophoresis was performed at a constant voltage of $150 \mathrm{~V}$ under nonreducing conditions. The gel was then washed as previously described ${ }^{30}$ : twice for 15 minutes each time in $50 \mathrm{mmol} / \mathrm{L}$ Tris buffer (containing $1 \mathrm{mmol} / \mathrm{L} \mathrm{Ca}^{2+}$ and $0.5 \mathrm{mmol} / \mathrm{L} \mathrm{Zn}^{2+}$ ) with $2.5 \%$ Triton $\mathrm{X}$-100; once for 5 minutes in Tris buffer alone; and finally in Tris buffer with $1 \%$ Triton X-100 for 5 days. The gels were stained with Sypro Ruby (Invitrogen), and the lytic band, reflecting degradation of elastin in the gel, was visualized.

\section{Flow Cytometry}

Inflammatory cells were collected from the blood via the right ventricle or from the minced lung. Red blood cells were removed using lysis buffer according to the manufacturer's instructions (Sigma). Isolated inflammatory cells were labeled with CD3, CD4, or CD8 antibodies conjugated with fluorophore (BD Pharmingen). A singlecell suspension was sorted on a BD FACS Aria (BD Biosciences, San Jose, CA) at the Stanford Shared FACS facility. Data were analyzed with FlowJo software (TreeStar Inc., Ashland, OR).

\section{Western Immunoblot Analysis}

Cultured cells or frozen lung tissues were lysed in icecold urea extraction buffer $(4 \mathrm{~mol} / \mathrm{L}$ urea in $0.016 \mathrm{~mol} / \mathrm{L}$ $\mathrm{KPO}_{4}$ ) containing protease and phosphatase inhibitors as previously described. The total protein in the sample was determined by the Lowry method (Bio-Rad, Hercules, CA), and $50 \mu \mathrm{g}$ of protein was resolved on a $4 \%$ to $12 \%$ NuPage Bis-Tris gel (Invitrogen) and electrotransferred to a nitrocellulose membrane. After blocking in freshly prepared $5 \%$ milk, the membranes were incubated overnight at $4^{\circ} \mathrm{C}$ with a primary antibody for murine NE (1:1000) (M-18; Santa Cruz Biotechnology, Santa Cruz, CA) or human NE (1:1000) (Abcam, Cambridge, $M A)$. The membrane was then incubated with either sheep anti-mouse or donkey anti-rabbit horseradish peroxidase-conjugated secondary antibodies. Autoradiographs were developed using the Amersham ECL plus kit (GE Healthcare, Little Chalfont, UK). Equal loading of protein was confirmed by immunoblotting for $\beta$-actin (1: 2000; Abcam). Densitometric analysis of the bands was then performed.

\section{Cell Culture}

Primary murine PA SMCs were isolated from S100A4 and C57 age and sex matched to those used in the study, using a modified elastase/collagenase digestion protocol. ${ }^{31}$ Central PAs were isolated from mice and digested in the dispersion medium containing $40 \mu \mathrm{mol} / \mathrm{L} \mathrm{CaCl}_{2}$, $0.5 \mathrm{mg} / \mathrm{mL}$ Elastase (Worthington Biochemical Corporation, Lakewood, NJ), $0.5 \mathrm{mg} / \mathrm{mL}$ collagenase (Worthington Biochemical Corporation), $0.2 \mathrm{mg} / \mathrm{mL}$ soybean trypsin inhibitor (Worthington Biochemical Corporation), and $2 \mathrm{mg} / \mathrm{mL}$ Albumin (Sigma-Aldrich, St. Louis, MO) for 20 minutes at $37^{\circ} \mathrm{C}$ as previously described. ${ }^{31}$ After filtration with $100-\mu \mathrm{m}$ cell strainers, PA SMCs were collected through centrifugation at $225 \mathrm{~g}$ for 6 minutes and subcultured with DMEM containing 10\% FBS and antibiotics (Invitrogen/Gibco). Primary human PA SMCs and PA endothelial cells were purchased from Lonza (Walkersville, $\mathrm{MD}$ ) and cultured according to the manufacturer's recommendation. Additional human PA SMCs were isolated from small to mid-size PAs (diameter, 1 to $5 \mathrm{~mm}$ ) harvested from lungs of patients with idiopathic PA hypertension (IPAH) removed at the time of lung transplantation, or from unused donor control lungs (see Supplemental Table S1 for patient characteristics at http://ajp.amjpathol.org). PAs were digested in the dispersion medium containing collagenase $(1000 \mathrm{U} / \mathrm{mL})$ (Sigma-Aldrich) for 1 hour at $37^{\circ} \mathrm{C}$ as previously described. ${ }^{32}$ After the filtration with $100-\mu \mathrm{m}$ cell strainers, PA SMCs were collected through centrifugation at $280 \mathrm{~g}$ for 10 minutes and subcultured with human PA SMC culture media (Lonza). All PA SMCs were assessed for immunoblotting, quantitative RT-PCR (RTQPCR), or elastase activity assay when the cells were passage 4 to 8 . 


\section{Statistical Analysis}

The number of animals or samples in each group is given in the figure legends. Statistical significance was determined by $\chi^{2}$ statistics or one-way or two-way analysis of variance followed by a Bonferroni post hoc test when comparisons involved three or more groups. Pearson's correlation test was used to relate elastin fragmentation to vessels with a neointima. A $P$ value $<0.05$ was considered statistically significant. All morphometric analyses were performed by investigators blinded to the cohort being assessed.

\section{Results}

\section{Elastic Laminae of S100A4 Mice Are Susceptible to Degradation}

Previously, we reported that S100A4 versus C57 mice have thicker PA elastic laminae in association with increased production of fibulin-5. ${ }^{33}$ However, in response to treatment with NE, the S100A4 PAs produced larger amounts of elastin peptides compared to the C57 PAs, ${ }^{7}$ suggesting that the elastic laminae, although thicker, may also be poorly organized and susceptible to degradation. To visualize and to substantiate this feature, we examined the autofluorescent internal elastic lamina in the central PA by confocal microscopy, as previously described for systemic arteries. ${ }^{24}$ In the saline-perfused specimens, there was no difference in the number or size of fenestrations in the PA elastic lamina of C57 and S100A4 mice (Figure 1, A and B). However, in response to perfusion with porcine pancreatic elastase, the area of fenestrations was more than two times larger in S100A4 mice $(P<0.05)$ (Figure 1, C, D, and E). These data are consistent with the heightened susceptibility of elastic fibers of S100A4 mice to NE-mediated degradation.

\section{Fragmentation of PA Elastin in S100A4 Mice Is Associated with Neointimal Lesions}

We used Hart's stain to relate fragmentation of elastic laminae in intra-acinar PAs to the appearance of neointimal lesions in these vessels 6 months after M1-MHV-68 infection. We observed neointimal lesions in $40 \%$ of S100A4 but in none of the C57 PAs $(P<0.001$; Figure 2, $A$ and $B$ ). Although the numbers are relatively small, by using individual mice, we documented a significant correlation between the percentage of PAs with neointimal lesions and the percentage with fragmented elastic laminae, $(P<0.05)$ (see Supplemental Figure S1 at $h t t p: / /$ ajp.amjpathol.org). Fragmentation of elastic laminae generates elastin peptides and releases growth factors from the extracellular matrix, and these molecules can induce proliferation and migration of SMC. ${ }^{16}$ Indeed, we observed a significant increase in the number of proliferating SMC in the neointimal lesions of PAs in S100A4 versus C57 mice 6 months after M1-MHV-68 infection, as judged by positivity for proliferating cell nuclear antigen (PCNA) $(P<0.05$; Figure 2, $C$ and $D)$. Interestingly,
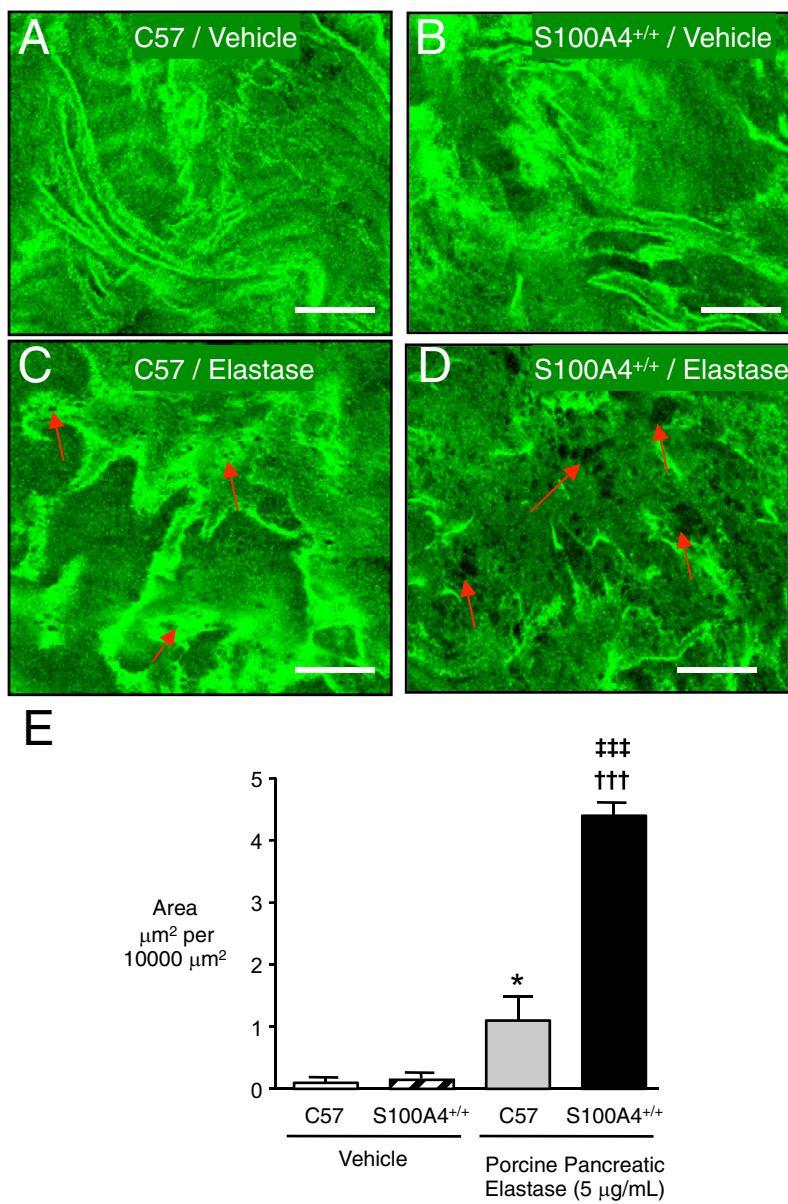

Figure 1. S100A4 PA elastic laminae are susceptible to elastase-mediated degradation. Representative confocal images of elastic laminae of central PAs from C57 (A and C) or S100A4 (B and D) mice after treatment with vehicle or porcine pancreatic elastase $(5 \mu \mathrm{g} / \mathrm{mL})$ as described in Materials and Methods. Scale bars: $25 \mu \mathrm{m}(\mathbf{A}-\mathbf{B})$. Note the increase in the size and number of fenestrations (arrows) in the S100A4 versus C57 PA treated with elastase (arrows). E: Quantification of area of fenestrae per total area of elastic lamina in S100A4 and C57 PAs following porcine pancreatic elastase $(5 \mu \mathrm{g} / \mathrm{mL})$ treatment. Bars represent mean \pm SEM of $n=3$ per group with ${ }^{*} P<0.05,{ }^{\text {tt }} P<0.001$ versus mice with the same genotype treated with vehicle; ${ }^{{ }^{*}} P<0.001$ versus C57 treated with porcine pancreatic elastase, by two-way analysis of variance followed by Bonferroni test.

formation of these neointimal lesions was not sufficient to elevate the right ventricular systolic pressure or to cause right ventricular hypertrophy (see Supplemental Figure S2 at http://ajp.amjpathol.org), a finding also observed in other models with neointimal lesions. ${ }^{2}$ This may reflect the fact that the lesions are present in less than half of the intra-acinar PAs and are not occlusive, so the pulmonary blood flow could easily be diverted to vessels without these abnormalities. We found no quantitative evidence of differences in muscularization or loss of peripheral arteries following viral inoculation (data not shown).

\section{S100A4 Mice Do Not Exhibit Increased Inflammation or Viral Load}

Heightened perivascular inflammation in the lung is a common feature of clinical and experimental pulmonary vascular disease. ${ }^{34}$ Therefore, we determined whether 
A
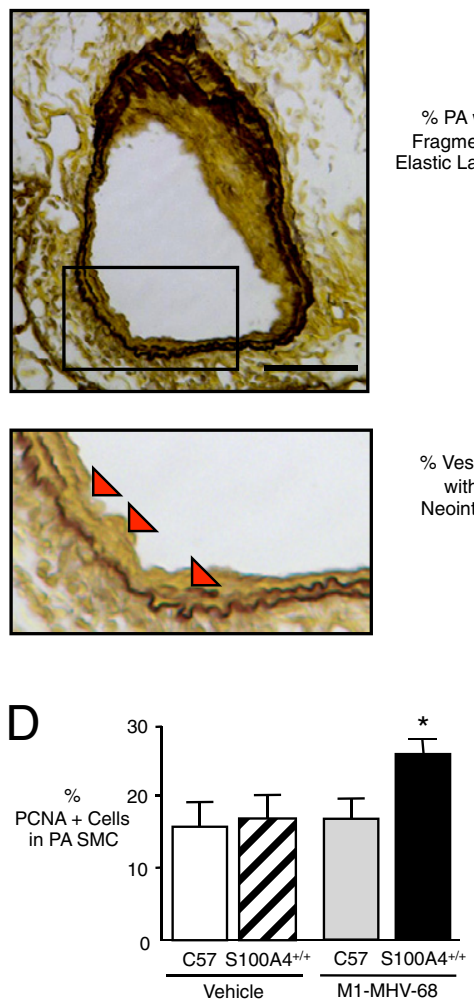

B
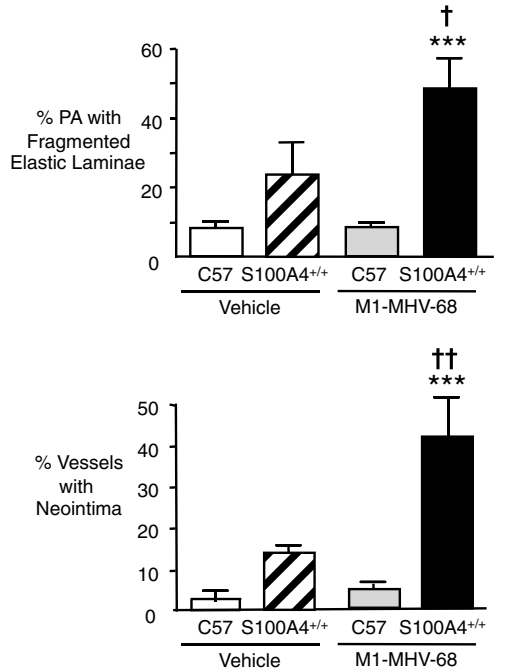

C
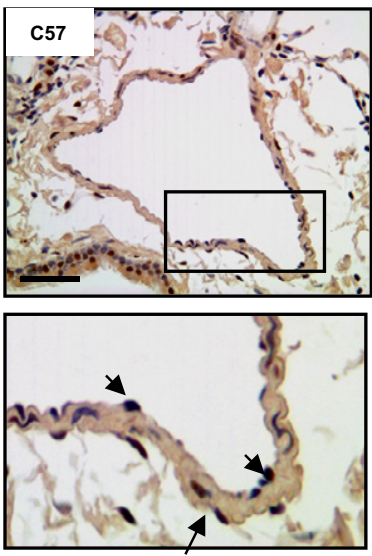
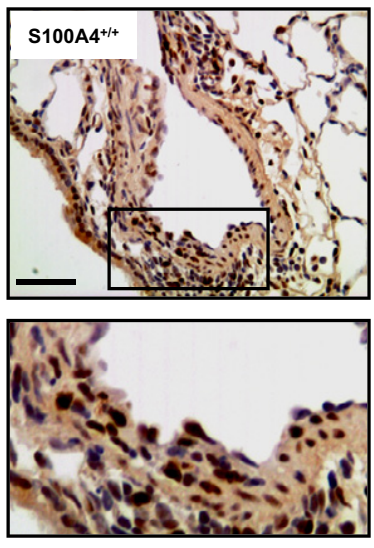

Figure 2. PAs with neointimal lesions exhibit fragmentation of elastic laminae and proliferating cells in S100A4 mice 6 months after viral infection. A: Representative S100A4 PA from a mouse 6 months after M1-MHV-68 viral infection, as visualized using Hart's stain. Fragmented elastic laminae are denoted by arrowheads in the higher magnification inset. Scale bar $=50 \mu \mathrm{m}$. B: Percentage of PAs exhibiting fragmented elastic laminae or neointimal lesions in C57 and S100A 4 mice treated with vehicle or M1-MHV-68. Bars represent mean \pm SEM of $n=5$ per group. ${ }^{\text {*atk }} P<0.001$ versus C57 mice with the viral infection; ${ }^{\dagger} P<0.05,{ }^{\dagger} P<0.01$ versus $\mathrm{S} 100 \mathrm{~A} 4$ treated with vehicle, by two-way analysis of variance followed by Bonferroni test $(\mathbf{C})$. Representative immunohistochemistry of PA expressing proliferating cell nuclear antigen (PCNA)positive cells in C57 and S100A 4 mice 6 months after viral infection (shown with higher magnification panel below). Arrows indicate region with dense brown nuclei reflecting PCNA ${ }^{+}$cells. Scale bar $=50 \mu \mathrm{m}$. D: Quantification of PCNA-positive cells per total cells in the PA walls. Bars represent mean \pm SEM of $n=7$ to 13 PAs per group. ${ }^{*} P<0.05$ for all other groups by two-way analysis of variance followed by Bonferroni test.

the elastin fragmentation in PAs of S100A4 mice might be related to elastase produced by a heightened inflammatory response, judged by the number or perivascular localization of inflammatory cells in the lung or by their state of activation as assessed by increased levels of interferon $\gamma$ or TNF $\alpha$. First, we investigated the level of $\mathrm{CD}^{+} \mathrm{T}$ cells, since these cells regulate viral replication in the lung and peripheral blood. However, although there was an elevation in the percentage of $\mathrm{CD}^{+}$cells in the peripheral blood and lung of S100A4 and C57 mice at 1 and 2 weeks after the viral infection, there was no significant genotype-related difference (Figure 3, A and B). Nor was there a genotype-related difference in the total number of peripheral blood mononuclear cells. At this time point, we saw very few neutrophils (by Ly-6G positivity) and no difference in the number of macrophages (Mac3 ${ }^{+}$cells), consistent with previous observations 3 months after viral infection. ${ }^{7}$ The increase in perivascular inflammatory cells was significant in the C57 group 2 weeks after viral infection $(P<0.05)$, but not in the S100A4 mice (Figure 3, C and D). Consistent with these findings, although we observed heightened cytokine production, as measured by lung mRNA expression of interferon $\gamma$ and $\mathrm{TNF} \alpha$ in both genotypes at 1 and 2 weeks after M1-MHV-68 infection $(P<0.01)$, the level of elevation was actually greater in the $\mathrm{C} 57$ group $(P<0.01$; Figure 4, A and B).

We then determined whether the ability to clear the virus might be impaired in the S100A4 versus C57 mice, and evaluated the viral load by PCR in both the lung and PAs. MHV-68-specific viral RNA [MHV-68 glycoprotein B
$(M H V-68 g B)]$ actively transcribed during viral replication. MHV-68 gB was present in reduced amounts in S100A4 versus C57 lungs 6 months after infection, and a similar trend was observed even at 1 week (Figure 5, A and B). Central PAs collected from S100A4 and C57 mice 1 week after viral infection showed similar levels of $M H V-68 g B$ RNA. Distal PAs (diameter $<100 \mu \mathrm{m}$ ) isolated from fixed tissue by laser capture microdissection of S100A4 and C57 lungs also expressed similar levels of MHV-68 viral DNA as assessed 6 months after infection (Figure 5, C and D).

\section{Serine Elastase Activity Is Increased in S100A4 Mouse Lungs Early after M1-MHV-68}

The results having shown no increase in the acute inflammatory response or in the magnitude of viral load in S100A4 versus C57 murine lungs, we investigated whether there was an early increase in elastase activity after M1-MHV-68 infection. We measured lung elastase activity 1 week after viral infection and documented a significant increase in the S100A4 mice, but only a trend in the C57 group ( $P<0.001$; Figure 6$)$. We confirmed that the elastase was a serine elastase and not a metalloelastase previously associated with lung parenchymal disease $^{35}$ since it was inhibited by recombinant human elafin $^{36}$ (Figure 6). We had previously documented an increase in lung serine elastase activity in S100A4 versus C57 mice 3 months after infection, ${ }^{7}$ a time point consistent with viral reactivation when neointimal lesions had 
A

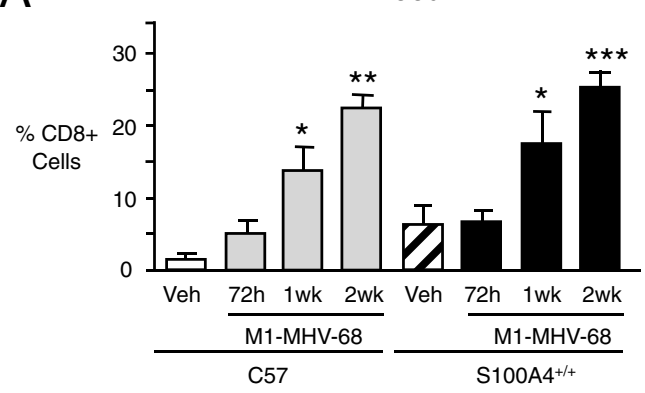

B

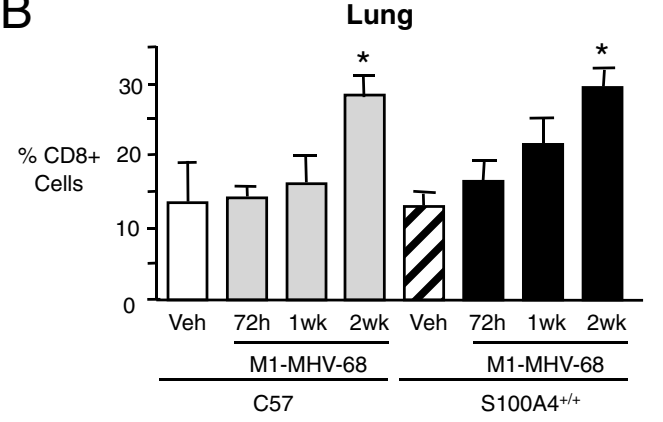

C C57
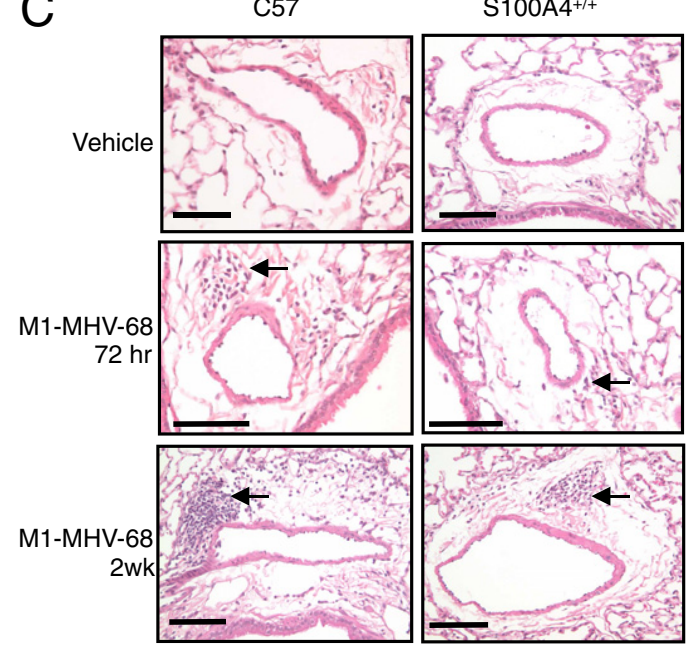

D

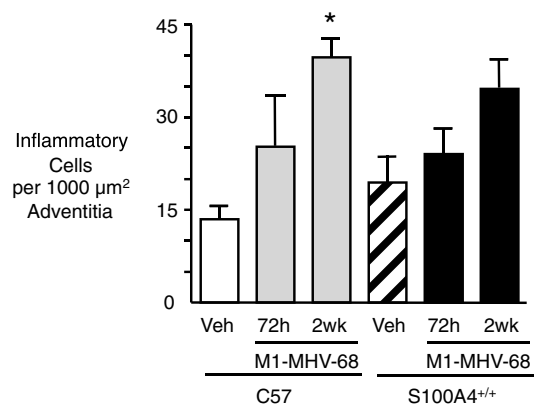

Figure 3. Early $\mathrm{CD}^{+}$cell response is similar, but perivascular inflammation may even be reduced in S100A4 versus C57 mice after M1-MHV-68 infection. $\mathrm{CD}^{+}$cells in the blood (A) and lungs (B) after the viral infection, as determined by fluorescence-activated cell sorter analysis. Bars represent mean \pm SEM of $n=3$ to 8 per group. ${ }^{*} P<0.05$, ${ }^{* * *} P<0.01$, and ${ }^{* * * * *} P<0.001$ versus mice with the same genotype treated with vehicle (Veh), by two-way analysis of variance followed by Bonferroni test. C: Perivascular inflammatory cells after M1-MHV-68 viral infection in the PAs, visualized by H\&E staining. Scale bars $=50 \mu \mathrm{m}$. Quantitative analysis of the number of inflammatory cells per area of adventitia (arrows) shown in (D). Bars represent mean \pm SEM of $n=15$ per group. ${ }^{*} P<0.05$ versus $\mathrm{C} 57$ treated with vehicle by two-way analysis of variance followed by Bonferroni test.
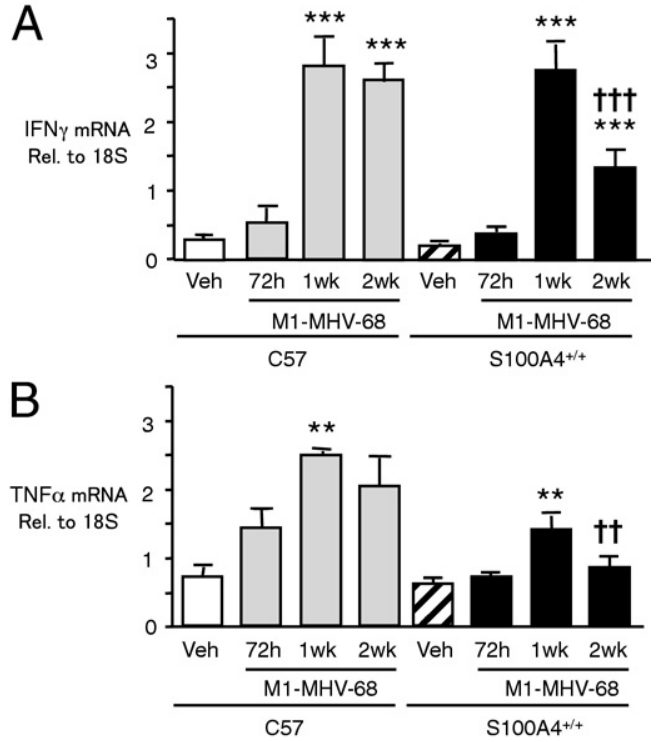

Figure 4. Early cytokine response is reduced in S100A4 versus C57 mice after M1-MHV-68 infection. mRNA levels of the representative cytokines IFN $\gamma$ (A) and TNF $\alpha$ (B), normalized to 18S RNA, in the lungs of C57 and S100A4 mice after M1-MHV-68 viral infection, as assessed by RT-qPCR. Bars represent mean \pm SEM of $n=3$ to 8 per group. ${ }^{* * *} P<0.01,{ }^{* * * *} P<0.001$ versus mice with the same genotype treated with vehicle (Veh). ${ }^{\dagger} P<0.01,{ }^{\mathrm{t}} P<$ 0.001 versus $C 57$ mice at the same time point after viral infection, by two-way analysis of variance followed by Bonferroni test.

already developed. ${ }^{7}$ We therefore determined whether the early increase in serine elastase activity predisposed to the formation of neointimal lesions observed in S100A4 mice 3 months later.

\section{Recombinant Elafin Diminishes PA Neointimal Lesions in S100A4 Mice after M1-MHV-68 Infection}

Intravenous administration of recombinant human elafin, at a dose of $2 \mathrm{mg} / \mathrm{kg} / \mathrm{day}$ was sufficient to inhibit the elevated serine elastase activity in lungs of S100A4 mice, assessed 1 week after inoculation with M1-MHV-68 (data not shown). Therefore, this dose was chosen for continuous infusion by mini-osmotic pump, beginning 1 day before and ending 1 month after the viral infection. We also evaluated the potential of recombinant elafin to reverse neointimal lesions by administering it between the third and fourth month after M1-MHV-68 infection. Because of considerable interanimal variability, we applied a $\chi^{2}$ statistic to analyze the number of vessels with neointimal lesions and assigned a score to the severity of these lesions judged by the number of layers of neointimal cells. Figure 7 illustrates the grading system applied to assess the presence and severity of a neointima. Grade 1 represents one cellular layer, Grade II, two cellular layers, and Grade III, three cellular layers. We show that when elafin was administered to prevent the early increase in elastase activity, the number and severity of neointimal lesions in the S100A4 mice was diminished $(P<0.001)$. Moreover, when elafin was administered between 3 and 4 months after viral infection, we also 

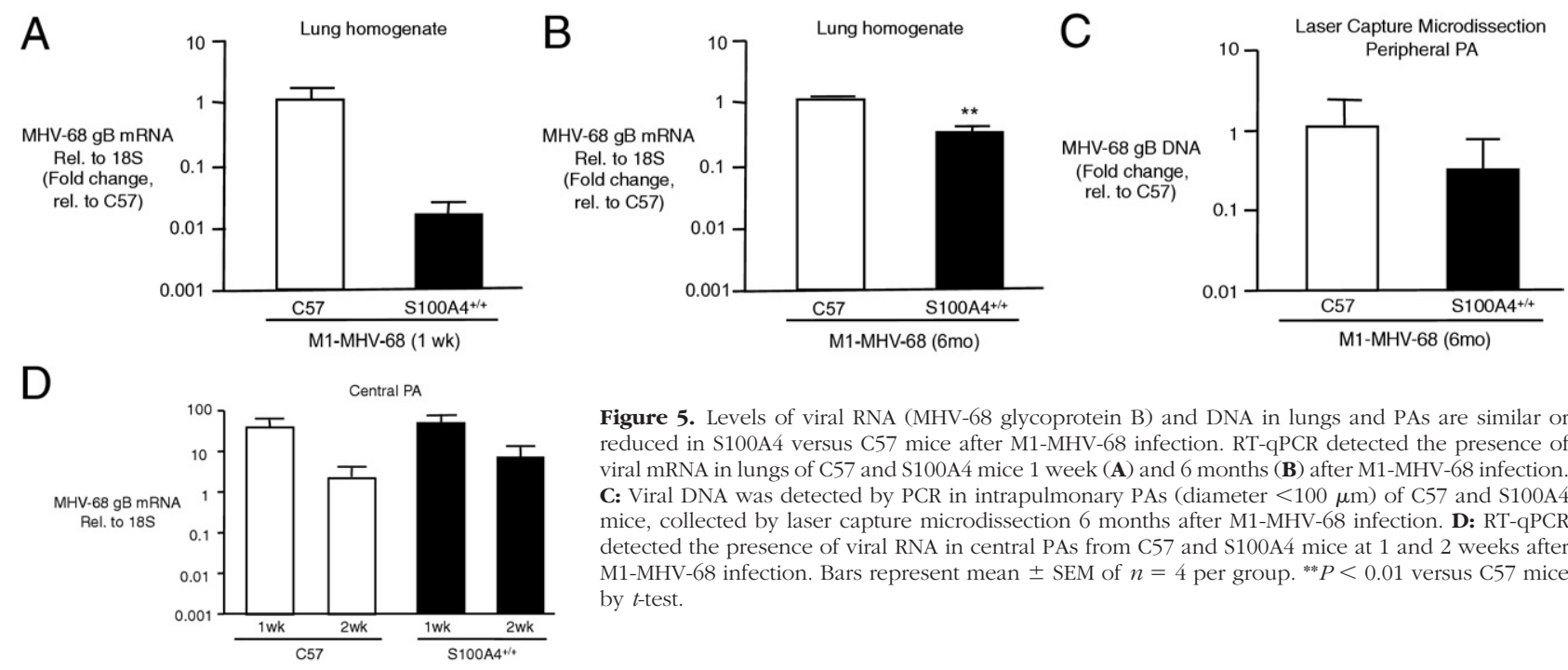

Figure 5. Levels of viral RNA (MHV-68 glycoprotein B) and DNA in lungs and PAs are similar or reduced in S100A4 versus C57 mice after M1-MHV-68 infection. RT-qPCR detected the presence of viral mRNA in lungs of C57 and S100A4 mice 1 week (A) and 6 months (B) after M1-MHV-68 infection. C: Viral DNA was detected by PCR in intrapulmonary PAs (diameter $<100 \mu \mathrm{m}$ ) of C57 and S100A4 mice, collected by laser capture microdissection 6 months after M1-MHV-68 infection. D: RT-qPCR detected the presence of viral RNA in central PAs from C57 and S100A4 mice at 1 and 2 weeks after M1-MHV-68 infection. Bars represent mean \pm SEM of $n=4$ per group. ${ }^{* *} P<0.01$ versus C57 mice by $t$-test.

observed a reduction in the number and severity of neointimal lesions $(P<0.05)$, although not a regression to the control uninfected state (Table 1).

\section{Neutrophil Elastase Is the Endogenous Vascular Elastase Expressed in PA SMC}

Although elafin is known to bind neutrophil elastase and proteinase-3 (reviewed in ${ }^{37}$ ), we did not exclude the possibility that there could be other elafin-inhibitable elastases in S100A4 lung after the viral infection. Furthermore, we had not identified the cell type that expresses this elafin-inhibitable elastase. To identify the nature and source of elastase activity that we had now related to the development and progression of neointimal lesions, we harvested the lungs from S100A4 overexpressing mice 1 week after viral infection, and prepared extracts as described in Materials and Methods. The lung extract was applied to a FLAG-immunoaffinity column to which we had conjugated FLAG-tagged human recombinant elafin. The elafin-bound proteins eluted were identified by mass spectrometry and were identical to sequences in NE (Figure $8 \mathrm{~A}$ ). A Western immunoblot demonstrated the presence of murine NE in the homogenate of the S100A4 lung, and elastin zymography revealed only one elastolytic band at $30 \mathrm{kDa}$, consistent with NE (Figure 8, B and
C). To investigate whether this enzymatic activity was produced by vascular cells, we isolated and cultured PA SMCs from C57 and S100A4 mice and, using passage 4 cells, confirmed expression of NE mRNA and protein. Furthermore, the level of NE mRNA was about threefold higher in PA SMCs isolated from the S100A4 versus the C57 cohort $(P<0.001)$, and there was a comparable increase in the amount of NE protein (Figure $8, D$ and E). We then assayed elastase activity using the fluorescent-labeled (DQ) elastin substrate and found a consistent increase in elastase activity in the cell culture medium of S100A4 versus C57 PA SMC $(P<0.05 ;$ Figure 8F). This total elastolytic activity represented a serine elastase fraction that was inhibited by elafin $(P<0.05)$ as well as a fraction that was not $(P<0.01)$, but in both cases, values were higher in S100A4 than in C57 PA SMC. Since elafin is a reversible inhibitor, it is possible that neutrophil elastase could contribute to the residual elastase activity that was not inhibited by elafin. ${ }^{38}$

\section{Neutrophil Elastase Is Expressed in PA SMCs from IPAH Patients}

To assess the clinical relevance of our observation, we examined the expression of NE in cells from human PAs.
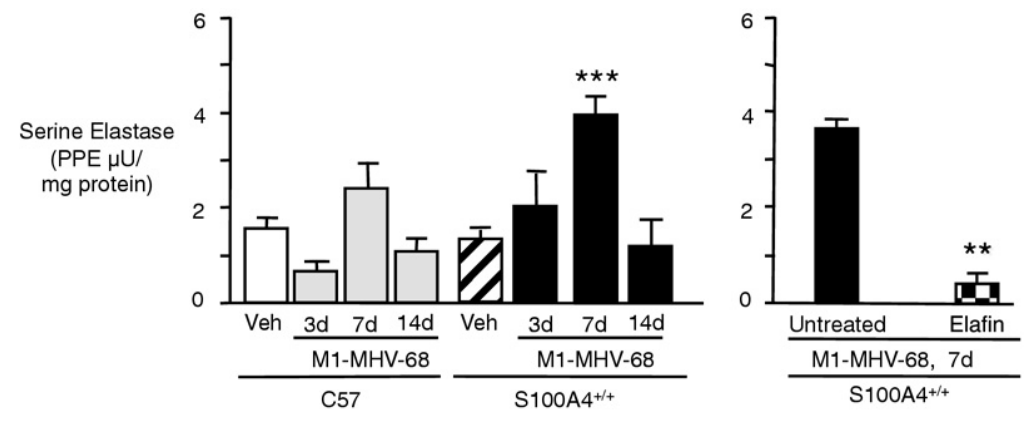

Figure 6. Serine elastase activity (inhibitable by elafin) is elevated in the S100A4 murine lung after M1-MHV-68 infection. Elafin-inhibitable serine elastase activity is compared in C57 and S100A 4 murine lungs at various time points up to 2 weeks after infection with M1-MHV-68 virus. Bars represent mean \pm SEM of $n=4$ per group. ${ }^{* *} P<0.01$ versus untreated, by $t$-test; ${ }^{* * *} P<0.001$ versus $100 \mathrm{~A} 4$ mice treated with vehicle (Veh) by two-way analysis of variance followed by Bonferroni test. 

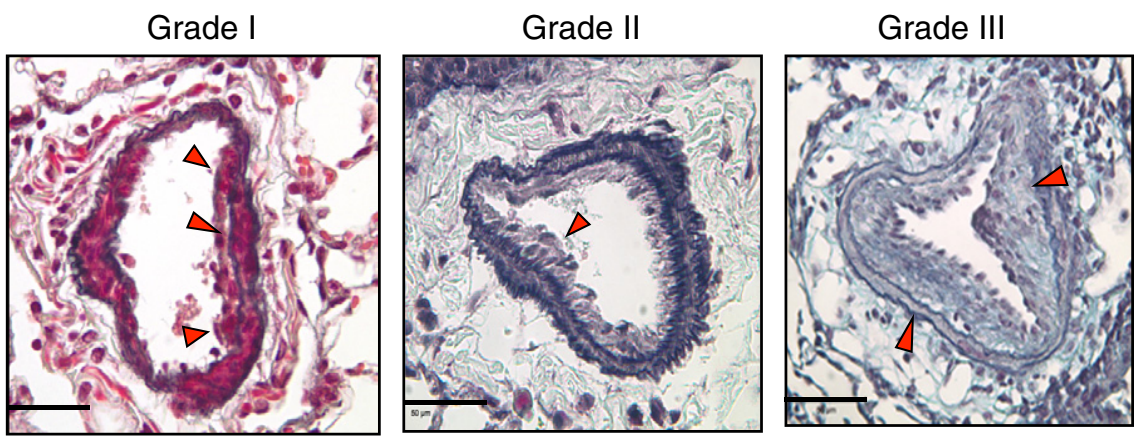

Figure 7. Grade of neointimal lesions induced by M1-MHV-68 in S100A4 mice. Representative photomicrographs of the neointima of PAs from different S100A4 mice infected with M1-MHV-68. Neointimal lesions are categorized as grade I (focal neointima with one layer), grade II (two layers of neointima), or grade III (three or more layers of neointima). Arrowheads indicate areas of neointima in Grade I and Grade II panels and internal and external elastic laminae in Grade III panel. Scale bars $=50 \mu \mathrm{m}$.

We detected NE mRNA in commercially available human PA SMCs, but not in PA endothelial cells (see Supplemental Figure S3 at http://ajp.amjpathol.org). Furthermore, PA SMCs harvested from patients with IPAH versus unused donor lungs showed elevated expression of NE $(P<0.05)$ (Figure 9A). Immunoreactivity for NE was present in neutrophils of IPAH and control lungs, and in the neointima (Figure 9B) and in plexiform lesions of IPAH lungs (Figure 9D; see also Supplemental Table S1 for patient characteristics at http://ajp.amjpathol.org).

\section{Discussion}

Our study shows, for the first time to our knowledge, that NE is produced by PA SMCs and is elevated in experimental and clinical pulmonary vascular disease. Moreover, we provide evidence linking the activity of this enzyme to the propensity to develop neointimal lesions in response to a viral infection.

We previously described fragmentation of elastin in the intra-acinar arteries as an early feature of $\mathrm{PAH}^{11}$ as assessed by ultrastructural analysis of lung biopsy tissue obtained from patients with congenital heart disease. In this study, we were able to relate fragmentation of elastin in PAs to neointimal lesions using light microscopy. We then applied confocal microscopy to show that the elastin in the S100A4 PA is susceptible to degradation. Since the elastic laminae in PAs of S100A4 mice are thicker than those of C57 controls, and the elastin is cross-linked, their susceptibility to degradation may be related to the high proportion of fibuin-5 we previously demonstrated, ${ }^{33}$ and to our more recent unpublished finding that there is also an increase in fibulin-2. These fibulins are microfibrillarscaffolding proteins that can promote self-aggregation (coacervation) and cross-linking of tropoelastin. ${ }^{39,40}$ Fibulin-2 is increased in neointimal lesions in an atherosclerosis model, and in the dermis of sun-exposed skin, related to elastolysis. ${ }^{41,42}$ This suggests that a high proportion of fibulin in elastic laminae may be evidence of elastic fibers that have undergone degradation and repair. The repair process may produce fibers that are susceptible to degradation, because the elastin within the fiber is of variable thickness.

We attributed the source of the virus-mediated heightened serine elastase activity in the S100A4 versus C57 murine lungs to the PA SMC. Since we had shown in previous studies ${ }^{17,43}$ that endothelial or serum factors can induce PA SMC production of a serine elastase, it is possible that the virus induces endothelial injury and permeability. Since viral load was not greater, the increase in elastase activity in the S100A4 versus C57 mice reflects heightened sensitivity to a perturbing factor. This sensitivity to perturbation may explain the higher levels of NE in the cultured PA SMC from uninfected S100A4 versus $\mathrm{C} 57$ mice. Since administration of S100A4 or knockdown of S100A4 had no impact on the ability of PA SMC to produce NE (see Supplemental Figure S4 at http://ajp.amjpathol.org), we speculate that enhanced elastase production could have resulted from an epigenetic alteration induced by S100A4 that is unmasked by the combination of aging and infection or by con-

Table 1. rElafin Attenuates Neointimal Lesion Formation after Viral Infection

\begin{tabular}{|c|c|c|c|c|c|c|}
\hline \multirow[b]{2}{*}{ Inhibition } & \multirow[b]{2}{*}{ Treatment $(n)$} & \multirow[b]{2}{*}{ Normal PAs $(n)$} & \multicolumn{4}{|c|}{ PAs with neointima $(n)$} \\
\hline & & & Total & Grade I & Grade II & Grade III \\
\hline \multirow[t]{2}{*}{ Lytic replication phase } & Saline (9) & 197 & 116 & 90 & 21 & 5 \\
\hline & rElafin (8) & 167 & $50 *$ & 41 & 6 & 3 \\
\hline \multirow[t]{2}{*}{ Reactivation phase } & Saline (7) & 140 & 57 & 31 & 14 & 12 \\
\hline & rElafin (5) & 148 & $36^{+}$ & 26 & 9 & 1 \\
\hline
\end{tabular}

The S100A4 treatment groups and the number $(n)$ of mice in each are shown. The total number of normal PAs in the section is given as well as the number classified by the different grades of neointima (Grade 1, II, or III) in S100A4 overexpressing mice, infected with M1-MHV-68, and treated with saline vehicle or recombinant elafin (rElafin).

First series: Treatment was begun prior to the inoculation of the virus to inhibit elastase activity during the viral lytic replication phase, and the mice were sacrificed 3 months later to evaluate the extent and severity of neointimal lesions. $\chi^{2}=11.7, \mathrm{df}=1,{ }^{\star} P<0.001$.

Second series: Mice were treated with recombinant elafin or vehicle beginning on the third month after the viral infection to inhibit elastase activity during the "viral reactivation phase." $\chi^{2}=4.53, \mathrm{df}=1, P<0.05$, Grade II + III: $\chi^{2}=7.14$, df $=1,{ }^{\dagger} P<0.01$ 
$\mathrm{B}$

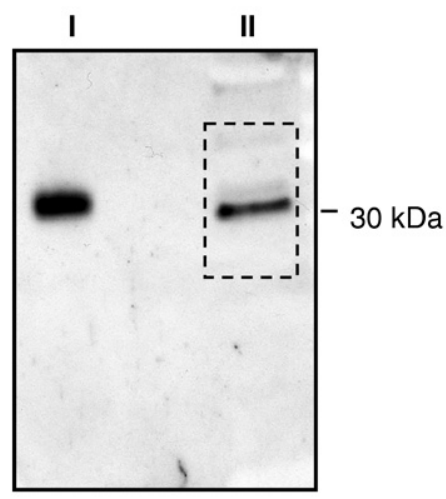

Anti-Neutrophil Elastase
C

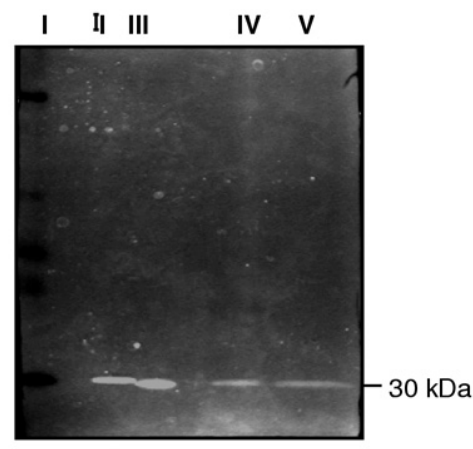

Elastin Zymogram
$E$

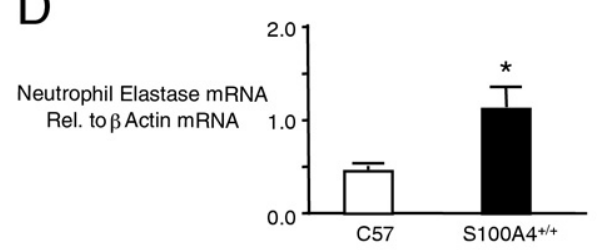

Neutrophil Elastase $\beta$ Actin C57 $\mathrm{S} 100 \mathrm{~A} 4^{+/+}$

$\mathrm{F}$

Elastase Activity (Fluorescence)

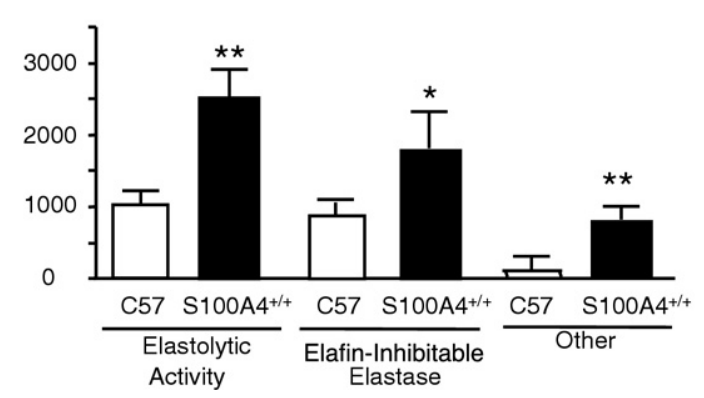

Figure 8. Heightened neutrophil elastase and elastolytic activity in PA SMCs from S100A4 versus C57 mice. A: Mass spectrometry analysis of eluate from FLAG-elafin-conjugated column following incubation with lung homogenate revealed two peptides with $100 \%$ identity to murine neutrophil elastase. The peptide sequences are in bold and underscored. B: Neutrophil elastase protein was detected in S100A4 murine lungs 1 week after viral infection by Western immunoblot analysis (B, lane II). As a positive control, recombinant neutrophil elastase is shown (B, lane I). C: Elastolytic activity from S100A4 mouse lung 1 week after viral infection was detected at $30 \mathrm{kDa}$ on the elastin zymogram (C, lanes IV and $\mathbf{V}$ ). Porcine pancreatic elastase and human neutrophil elastase were used as positive controls (C, lanes II and III) Quantitative RT-PCR to demonstrate neutrophil elastase mRNA in (D) and Western immunoblot analysis to show neutrophil elastase protein in $(\mathbf{E})$ in cultured PA SMCs from S100A4 mice and C57 mice. F: Elastolytic activity attributed to elafininhibitable elastase or other elastases detected in the cell culture medium from eight S100A4 and four C57 PA SMCs. Bars represent mean \pm SEM. ${ }^{*} P<0.05,{ }^{* *} P<0.01$, and ${ }^{* *} P<0.001$ versus matched control, by $t$-test. ditions of culture. This possibility will be pursued in future studies.

We previously documented that PA SMC elastase activity results in the release of biologically active SMC mitogens, such as FGF-2, from the extracellular matrix. ${ }^{16}$ Elastase also activates matrix metalloproteinases (MMPs) that degrade native type I collagen, and, in so doing, expose cryptic RGD sites that preferentially bind $\alpha_{\mathrm{v}} \beta_{3}$ integrins, and stimulate tenascin $\mathrm{C}$ production. Enhanced production of tenascin C clusters $\alpha_{\mathrm{v}} \beta_{3}$ integrins and activates growth factor receptors such as epidermal growth factor receptors. ${ }^{20}$ The combination of released growth factors and activated growth factor receptors could explain the proliferative response leading to neointimal formation.

The propensity to degrade elastin and to develop intimal lesions has been related to aging ${ }^{44}$ because only the S100A4 mice over 1 year of age develop neointimal lesions after viral infection. It is therefore of further interest that, in the rat brain, RAGE, the receptor for S100A4, is increased with aging. ${ }^{45}$

The S100A4 overexpressing mice also show a relatively minor increase in PA SMC elastase activity that is not inhibited by elafin and may reflect enhanced production of elastolytic MMPs, also implicated in vascular pathobiology. ${ }^{46}$ Consistent with this, we have shown in cultured PA SMC that S100A4 can induce activity of MMP 2 and 9 via pERK. ${ }^{47}$ The early transient increase in lung elastase activity after viral infection was completely inhibited by elafin, suggesting that there was negligible nonserine elastase activity associated with the acute response to the viral inoculum.

Our previous experimental models using a variety of NE inhibitors showed that the enzyme contributes to the pathogenesis of a broad range of cardiovascular diseases, including myocardial infarction, ${ }^{48}$ intimal thickening in the carotid artery after wire-induced endothelial denudation $^{49}$ or repeated balloon angioplasty, ${ }^{50}$ coronary arteri- 

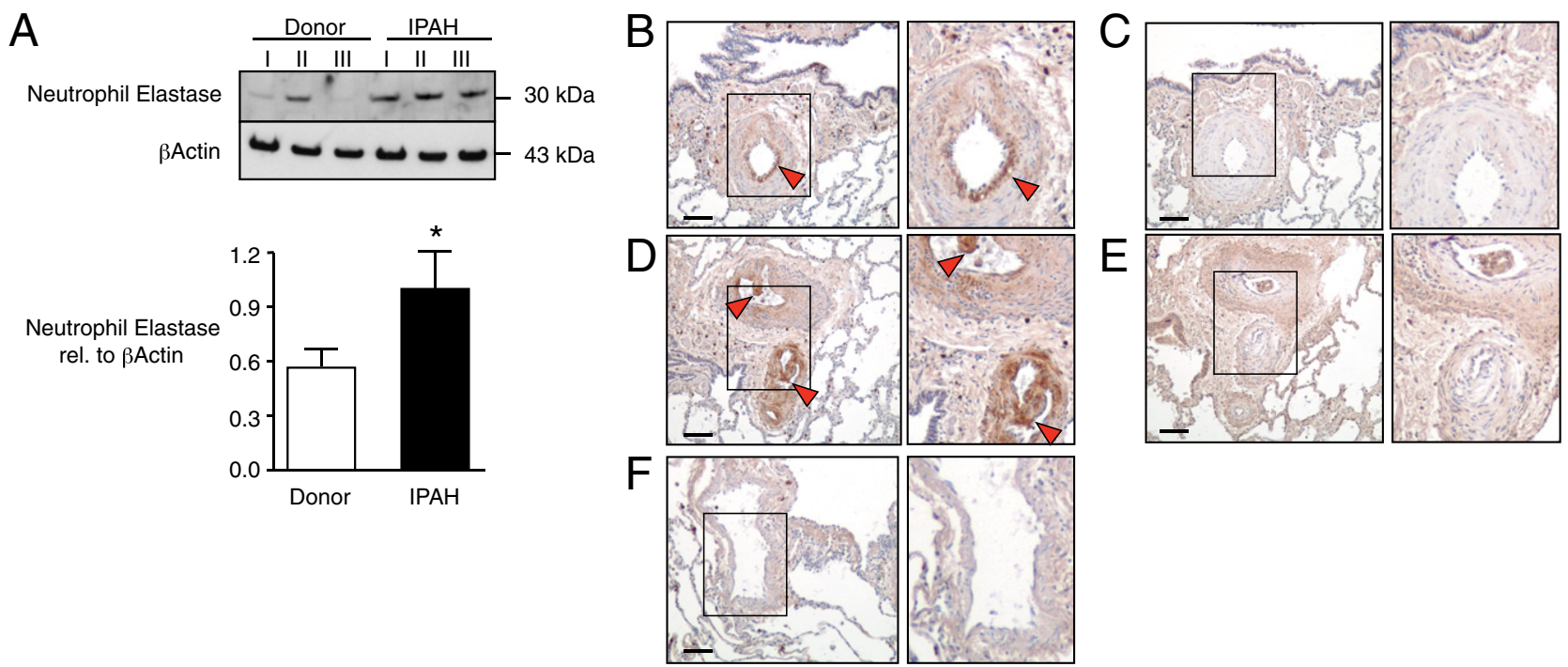

Figure 9. Heightened neutrophil elastase expression in cultured PA SMCs is localized to neointimal lesions in lungs from IPAH patients. A: Western immunoblots on top and relative densitometry on the bottom comparing NE relative to $\beta$ actin in cultured PA SMCs isolated from three IPAH patients versus three unused donor lungs as controls. Bars represent mean of $n=3$ per group, with ${ }^{*} P<0.05$ determined by $t$-test. Representative immunohistochemistry from one of five IPAH and one of four control lungs. Cells strongly expressing neutrophil elastase are apparent in the subendothelium and media of PAs with neointimal or plexiform lesions in the IPAH lung (B and D). Little immunoreactivity for NE was apparent in the PAs in the control donor lung (F). Background immunoreactivity is apparent using IgG as a control ( $\mathbf{C}$ and E). Arrowheads point to regions of intense immunoreactivity. Marked areas are shown with twofold higher magnification, on the right. Scale bars, $100 \mu \mathrm{m}$ (B-F).

opathy after transplantation, ${ }^{28,51}$ vein graft atherosclerosis $^{52}$ and fibrosis following viral myocarditis, ${ }^{53,54}$ or pulmonary hypertension induced by hypoxia ${ }^{12,14}$ or monocrotaline. ${ }^{13,15}$ In five of these models, ${ }^{28,50,52,54}$ elafin was used as the elastase inhibitor, given as an infusion, ${ }^{28}$ by gene therapy ${ }^{50,52}$ or in an overexpressing transgenic mouse. $^{14,49,54}$

Elafin is a small, 9-kDa protein, first described in association with inflammatory lesions in the airways ${ }^{55}$ and with psoriasis in skin. ${ }^{56}$ It is secreted as a $12-\mathrm{kDa}$ proform containing a transglutaminase domain that also has elastase inhibitory properties. The only known substrates of elafin are NE and proteinase 3. It is a potent antimicrobial and anti-inflammatory agent (reviewed in Ref. 37), and it can be produced by gamma delta T cells, ${ }^{57}$ among other cells, including vascular cells. Elafin also has anti-HIV protease activity ${ }^{58}$ and is proapoptotic in melanoma cells. ${ }^{59}$

Our studies using elafin to inhibit the early increase in NE activity suggest that it contributes to the later development of neointimal lesions. We also showed that the later increase in NE activity previously documented with reactivation of the virus at 3 months ${ }^{7}$ can have an impact on the progressive development of these vascular abnormalities. Neutrophil elastase has been observed in endothelial cells and macrophages ${ }^{60}$ and can be produced by lymphocytes. Interestingly, in neutrophils, the elastase mRNA transcript is undetectable, but the protein is stored in azurophilic granules. ${ }^{61}$ We showed, using commercially available cultured human PA vascular cells, that the NE mRNA, as well as the protein, is present in SMCs even after six passages in culture, but not in endothelial cells, suggesting that this finding is unlikely to be attributable to mRNA in microparticles from neutrophils. This is, to our knowledge, the first documentation of the expression of NE mRNA as well as protein in PA SMCs, and may represent the NE previously described in aneurysm ally dilated aortic tissues. ${ }^{62}$ However, since recombinant elafin has been reported to have anti-HIV activity, we cannot exclude the possibility that elafin may have anti-M1-MHV-68 activity and that this could have contributed to the inhibition of neointimal lesion development. ${ }^{63}$

It is of interest that our previous studies identified heightened expression of S100A4 in the neointimal and plexiform lesions of patients with IPAH, ${ }^{6}$ because we also saw these lesions as sources of NE immunoreactivity. Moreover, we documented elevated NE protein levels in the PA SMC harvested from the lungs of these patients versus those from unused donor control lungs. We speculate that the NE expressed by cells in the advanced vascular lesions may contribute to ongoing degradation and impaired repair of the elastic laminae, and in so doing could induce progressive proliferation of the vascular cells, and recruitment of inflammatory cells. ${ }^{64}$

Taken together, our study provides the first evidence to our knowledge that NE is produced by murine and human PA SMC. We show a link between the activity of this enzyme and the propensity to develop neointimal lesions in response to a viral infection in a murine model of pulmonary vascular disease, a link that may point to an essential role of this enzyme in human disease, and to a potential therapy.

\section{Acknowledgments}

We appreciate the help of Dr. Michal Bental Roof in preparing this manuscript. We also appreciate the kind gifts of reagents from Dr. Jason Weinberg (University of 
Michigan) and Dr. Ren Sun (University of California Los Angeles) for experiments not included in the manuscript.

\section{References}

1. Rabinovitch M: Molecular pathogenesis of pulmonary arterial hypertension. J Clin Invest 2008, 118:2372-2379

2. Daley E, Emson C, Guignabert C, de Waal Malefyt R, Louten J, Kurup VP, Hogaboam C, Taraseviciene-Stewart L, Voelkel NF, Rabinovitch M, Grunig E, Grunig G: Pulmonary arterial remodeling induced by a Th2 immune response. J Exp Med 2008, 205:361-372

3. Crosby A, Jones FM, Southwood M, Stewart S, Schermuly R, Butrous G, Dunne DW, Morrell NW: Pulmonary vascular remodeling correlates with lung eggs and cytokines in murine schistosomiasis. Am J Respir Crit Care Med 2010, 181:279-288

4. Abe K, Toba M, Alzoubi A, Ito M, Fagan KA, Cool CD, Voelkel NF, McMurtry IF, Oka M: Formation of plexiform lesions in experimental severe pulmonary arterial hypertension. Circulation 2010, 121:27472754

5. Steiner MK, Syrkina OL, Kolliputi N, Mark EJ, Hales CA, Waxman AB: Interleukin-6 overexpression induces pulmonary hypertension. Circ Res 2009, 104:236-244

6. Greenway S, van Suylen RJ, Du Marchie Sarvaas G, Kwan E, Ambartsumian N, Lukanidin E, Rabinovitch M: S100A4/Mts1 produces murine pulmonary artery changes resembling plexogenic arteriopathy and is increased in human plexogenic arteriopathy. Am J Patho 2004, 164:253-262

7. Spiekerkoetter E, Alvira CM, Kim YM, Bruneau A, Pricola KL, Wang L, Ambartsumian N, Rabinovitch M: Reactivation of \{gamma\}HV68 induces neointimal lesions in pulmonary arteries of S100A4/Mts1 overexpressing mice in association with degradation of elastin. Am J Physiol Lung Cell Mol Physiol 2008, 294:L276-289

8. Grigorian M, Ambartsumian N, Lykkesfeldt $A E$, Bastholm L, Elling $F$, Georgiev G, Lukanidin E: Effect of mts1 (S100A4) expression on the progression of human breast cancer cells. Int J Cancer 1996, 67:831-841

9. Cool CD, Rai PR, Yeager ME, Hernandez-Saavedra D, Serls AE, Bull TM, Geraci MW, Brown KK, Routes JM, Tuder RM, Voelkel NF: Expression of human herpesvirus 8 in primary pulmonary hypertension. N Engl J Med 2003, 349:1113-1122

10. Bendayan D, Sarid R, Cohen A, Shitrit D, Shechtman I, Kramer MR: Absence of human herpesvirus 8 DNA sequences in lung biopsies from Israeli patients with pulmonary arterial hypertension. Respiration 2008, 75:155-157

11. Rabinovitch M, Bothwell T, Hayakawa BN, Williams WG, Trusler GA, Rowe RD, Olley PM, Cutz E: Pulmonary artery endothelial abnormalities in patients with congenital heart defects and pulmonary hypertension. A correlation of light with scanning electron microscopy and transmission electron microscopy. Lab Invest 1986, 55:632-653

12. Maruyama K, Ye CL, Woo M, Venkatacharya H, Lines LD, Silver MM, Rabinovitch M: Chronic hypoxic pulmonary hypertension in rats and increased elastolytic activity. Am J Physiol 1991, H1716-1726

13. Ye C, Rabinovitch M: Inhibition of elastolysis by SC-37698 reduces development and progression of monocrotaline pulmonary hypertension. Am J Physiol 1991, 261:H1255-H1267

14. Zaidi SHE, You X-M, Ciura S, Husain M, Rabinovitch M: Overexpression of the serine elastase inhibitor elafin protects transgenic mice from hypoxic pulmonary hypertension. Circulation 2002, 105: $516-521$

15. Cowan KN, Heilbut A, Humpl T, Lam C, Ito S, Rabinovitch M: Complete reversal of fatal pulmonary hypertension in rats by a serine elastase inhibitor. Nat Med 2000, 6:698-702

16. Thompson K, Rabinovitch M: Exogenous leukocyte and endogenous elastases can mediate mitogenic activity in pulmonary artery smooth muscle cells by release of extracellular-matrix bound basic fibroblast growth factor. J Cell Physiol 1996, 166:495-505

17. Thompson K, Kobayashi J, Childs T, Wigle D, Rabinovitch M: Endothelial and serum factors which include apolipoprotein $\mathrm{A} 1$ tether elastin to smooth muscle cells inducing serine elastase activity via tyrosine kinase-mediated transcription and translation. J Cell Physiol 1998, 174:78-89
18. Wigle DA, Thompson KE, Yablonsky S, Zaidi SHE, Coulber C, Jones PL, Rabinovitch M: AML1-like transcription factor induces serine elastase activity in ovine pulmonary artery smooth muscle cells. Circ Res 1998, 83:252-263

19. Mitani $Y$, Zaidi SHE, Dufourcq $P$, Thompson K, Rabinovitch M: Nitric oxide reduces vascular smooth muscle cell elastase activity through cGMP-mediated suppression of ERK phosphorylation and AML1B nuclear partitioning. FASEB J 2000, 14:805-814

20. Jones P, Crack J, Rabinovitch M: Regulation of tenascin-C, a vascular smooth muscle cell survival factor that interacts with the $\alpha \vee \beta 3$ integrin to promote epidermal growth factor receptor phosphorylation and growth. J Cell Biol 1997, 139:279-293

21. Ambartsumian N, Klingelhofer J, Grigorian M, Karlstrom O, Sidenius N, Georgiev G, Lukanidin E: Tissue-specific posttranscriptional downregulation of expression of the S100A4(mts1) gene in transgenic animals. Invasion Metastasis 1998, 18:96-104

22. Ambartsumian N, Klingelhofer J, Grigorian M, Christensen C, Kriajevska M, Tulchinsky E, Georgiev G, Berezin V, Bock E, Rygaard J, Cao R, Cao Y, Lukanidin E: The metastasis-associated Mts1(S100A4) protein could act as an angiogenic factor. Oncogene 2001, 20:46854695

23. Lawrie A, Spiekerkoetter E, Martinez EC, Ambartsumian N, Sheward WJ, Maclean MR, Harmar AJ, Schmidt AM, Lukanidin E, Rabinovitch $\mathrm{M}$ : Interdependent serotonin transporter and receptor pathways regulate S100A4/Mts1, a gene associated with pulmonary vascular disease. Circ Res 2005, 97:227-235

24. Wong LC, Langille BL: Developmental remodeling of the internal elastic lamina of rabbit arteries: effect of blood flow. Circ Res 1996 78:799-805

25. Jackson ZS, Gotlieb AI, Langille BL: Wall tissue remodeling regulates longitudinal tension in arteries. Circ Res 2002, 90:918-925

26. Gonzalez JM, Briones AM, Somoza B, Daly CJ, Vila E, Starcher B, McGrath JC, Gonzalez MC, Arribas SM: Postnatal alterations in elastic fiber organization precede resistance artery narrowing in SHR Am J Physiol Heart Circ Physiol 2006, 291:H804-812

27. Guignabert C, Alvira CM, Alastalo TP, Sawada H, Hansmann G, Zhao M, Wang L, El-Bizri N, Rabinovitch M: Tie2-mediated loss of peroxisome proliferator-activated receptor-gamma in mice causes PDGF receptor-beta-dependent pulmonary arterial muscularization. Am J Physiol Lung Cell Mol Physiol 2009, 297:L1082-1090

28. Cowan B, Baron O, Crack J, Coulber C, Wilson GJ, Rabinovitch M: Elafin, a serine elastase inhibitor, attenuates post-cardiac transplant coronary arteriopathy and reduces myocardial necrosis in rabbits after heterotopic cardiac transplantation. J Clin Invest 1996, 97:24522468

29. Weinberg JB, Lutzke ML, Alfinito R, Rochford R: Mouse strain differences in the chemokine response to acute lung infection with a murine gammaherpesvirus. Viral Immunol 2004, 17:69-77

30. Gibbs DF, Warner RL, Weiss SJ, Johnson KJ, Varani J: Characterization of matrix metalloproteinases produced by rat alveolar macrophages. Am J Respir Cell Mol Biol 1999, 20:1136-1144

31. Fouty BW, Grimison B, Fagan KA, Le Cras TD, Harral JW, HoedtMiller M, Sclafani RA, Rodman DM: p27(Kip1) is important in modulating pulmonary artery smooth muscle cell proliferation. Am J Respir Cell Mol Biol 2001, 25:652-658

32. Yang X, Lee PJ, Long L, Trembath RC, Morrell NW: BMP4 induces HO-1 via a Smad-independent, p38MAPK-dependent pathway in pulmonary artery myocytes. Am J Respir Cell Mol Biol 2007, 37 $598-605$

33. Merklinger SL, Wagner RA, Spiekerkoetter E, Hinek A, Knutsen RH, Kabir MG, Desai K, Hacker S, Wang L, Cann GM, Ambartsumian NS, Lukanidin E, Bernstein D, Husain M, Mecham RP, Starcher B, Yanagisawa $\mathrm{H}$, Rabinovitch $\mathrm{M}$ : Increased fibulin-5 and elastin in S100A4/ Mts1 mice with pulmonary hypertension. Circ Res 2005, 97:596-604

34. Tuder RM, Groves B, Badesch DB, Voelkel NF: Exuberant endothelial cell growth and elements of inflammation are present in plexiform lesions of pulmonary hypertension. Am J Pathol 1994, 144:275-285

35. Parks WC, Shapiro SD: Matrix metalloproteinases in lung biology. Respir Res 2001, 2:10-19

36. Wiedow O, Schroder JM, Gregory H, Young JA, Christophers E: Elafin, an elastase specific inhibitor of human skin. J Biol Chem 1990, 265:14791-14795 
37. Sallenave JM: Secretory leukocyte protease inhibitor and elafin/ trappin-2: versatile mucosal antimicrobials and regulators of immunity. Am J Respir Cell Mol Biol 2010, 42:635-643

38. Ying QL, Simon SR: Kinetics of the inhibition of human leukocyte elastase by elafin, a 6-kilodalton elastase-specific inhibitor from human skin. Biochemistry 1993, 32:1866-1874

39. Nakamura T, Lozano PR, Ikeda Y, Iwanaga Y, Hinek A, Minamisawa S, Cheng CF, Kobuke K, Dalton N, Takada Y, Tashiro K, Ross J Jr, Honjo T, Chien KR: Fibulin-5/DANCE is essential for elastogenesis in vivo. Nature 2002, 415:171-175

40. Chapman SL, Sicot FX, Davis EC, Huang J, Sasaki T, Chu ML, Yanagisawa $\mathrm{H}$ : Fibulin-2 and fibulin-5 cooperatively function to form the internal elastic lamina and protect from vascular injury, Arterioscler Thromb Vasc Biol 2010;30:68-74

41. Strom A, Olin Al, Aspberg A, Hultgardh-Nilsson A: Fibulin-2 is present in murine vascular lesions and is important for smooth muscle cell migration. Cardiovasc Res 2006, 69:755-763

42. Hunzelmann N, Nischt R, Brenneisen P, Eickert A, Krieg T: Increased deposition of fibulin-2 in solar elastosis and its colocalization with elastic fibres. Br J Dermatol 2001, 145:217-222

43. Kobayashi J, Wigle D, Childs T, Zhu L, Keeley FW, Rabinovitch M: Seruminduced vascular smooth muscle cell elastolytic activity through tyrosine kinase intracellular signalling. J Cell Physiol 1994, 160:121-131

44. Jacob MP: Extracellular matrix remodeling and matrix metalloproteinases in the vascular wall during aging and in pathological conditions. Biomed Pharmacother 2003, 57:195-202

45. Thangthaeng N, Sumien N, Forster MJ: Dissociation of functional status from accrual of CML and RAGE in the aged mouse brain. Exp Gerontol 2008, 43:1077-1085

46. Bendeck MP, Irvin C, Reidy MA: Inhibition of matrix metalloproteinase activity inhibits smooth muscle cell migration but not neointimal thickening after arterial injury. Circ Res 1996, 78:38-43

47. Spiekerkoetter E, Guignabert C, de Jesus Perez V, Alastalo TP, Powers JM, Wang L, Lawrie A, Ambartsumian N, Schmidt AM, Berryman M, Ashley $\mathrm{RH}$, Rabinovitch M: S100A4 and bone morphogenetic protein-2 codependently induce vascular smooth muscle cell migration via phospho-extracellular signal-regulated kinase and chloride intracellular channel 4. Circ Res 2009, 105:639-647

48. Ohta K, Nakajima T, Cheah AY, Zaidi SH, Kaviani N, Dawood F, You XM, Liu P, Husain M, Rabinovitch M: Elafin-overexpressing mice have improved cardiac function after myocardial infarction. Am J Physiol Heart Circ Physiol 2004, 287:H286-H292

49. Zaidi SH, You XM, Ciura S, O'Blenes S, Husain M, Rabinovitch M: Suppressed smooth muscle proliferation and inflammatory cell invasion after arterial injury in elafin-overexpressing mice. J Clin Invest 2000, 105:1687-1695

50. Barolet AW, Nili N, Cheema A, Robinson R, Natarajan MK, O'Blenes S, Li J, Eskandarian MR, Sparkes J, Rabinovitch M, Stauss BH: Arterial elastase activity after balloon angioplasty and effects of elafin, an elastase inhibitor. Arterioscler Thromb Vasc Biol 2001, 1269-1274
51. Oho S, Rabinovitch M: Post-cardiac transplant arteriopathy in piglets is associated with fragmentation of elastin and increased activity of a serine elastase. Am J Pathol 1994, 145:202-210

52. O'Blenes SB, Zaidi SHE, Cheah AYL, Mclntyre B, Kaneda Y, Rabinovitch M: Gene transfer of the serine elastase inhibitor elafin protects against vein graft degeneration. Circulation 2000, 102:III289-III295

53. Lee JK, Zaidi SH, Liu P, Dawood F, Cheah AY, Wen WH, Saiki Y, Rabinovitch M: A serine elastase inhibitor reduces inflammation and fibrosis and preserves cardiac function after experimentally-induced murine myocarditis. Nat Med 1998, 4:1383-1391

54. Zaidi SHE, Hui C-C, Cheah AYL, You X-M, Husain M, Rabinovitch M: Targeted overexpression of elafin protects mice against cardiac dysfunction and mortality following viral myocarditis. J Clin Invest 1999 103:1211-1219

55. Sallenave JM, Marsden MD, Ryle AP: Isolation of elafin and elastasespecific inhibitor (ESI) from bronchial secretions. Evidence of sequence homology and immunological cross-reactivity. Biol Chem Hoppe-Seyler 1992, 373:27-33

56. Schalkwijk J, van Vlijmen IM, Alkemade JA, de Jongh GJ: Immunohistochemical localization of SKALP/elafin in psoriatic epidermis. J Invest Dermatol 1993, 100:390-393

57. Marischen L, Wesch D, Schroder JM, Wiedow O, Kabelitz D: Human gammadelta $T$ cells produce the protease inhibitor and antimicrobial peptide elafin. Scand J Immunol 2009, 70:547-552

58. Ghosh M, Fahey JV, Shen Z, Lahey T, Cu-Uvin S, Wu Z, Mayer K, Wright PF, Kappes JC, Ochsenbauer C, Wira CR: Anti-HIV activity in cervical-vaginal secretions from HIV-positive and -negative women correlate with innate antimicrobial levels and IgG antibodies. PLoS One 2010, 5:e11366

59. Yu KS, Lee Y, Kim CM, Park EC, Choi J, Lim DS, Chung YH, Koh SS: The protease inhibitor, elafin, induces p53-dependent apoptosis in human melanoma cells. Int J Cancer 2009, 127:1308-1320

60. Dollery CM, Owen CA, Sukhova GK, Krettek A, Shapiro SD, Libby P: Neutrophil elastase in human atherosclerotic plaques: production by macrophages. Circulation 2003, 107:2829-2836

61. Fouret $P$, du Bois RM, Bernaudin JF, Takahashi H, Ferrans VJ, Crystal RG: Expression of the neutrophil elastase gene during human bone marrow cell differentiation. J Exp Med 1989, 169:833-845

62. Buckmaster MJ, Curci JA, Murray PR, Liao S, Allen BT, Sicard GA, Thompson RW: Source of elastin-degrading enzymes in mycotic aortic aneurysms: bacteria or host inflammatory response? Cardiovasc Surg 1999, 7:16-26

63. Ghosh M, Shen Z, Fahey JV, Cu-Uvin S, Mayer K, Wira CR: Trappin2/Elafin: a novel innate anti-human immunodeficiency virus-1 molecule of the human female reproductive tract. Immunology 2010, 129: 207-219

64. Antonicelli F, Bellon G, Debelle L, Hornebeck W: Elastin-elastases and inflamm-aging. Curr Top Dev Biol 2007, 79:99-155 